Pamiętnik Literacki 2019, 1, s. 57-76

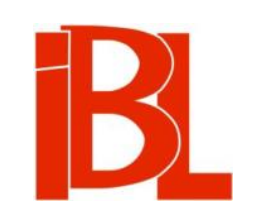

\title{
Tadeusza Konwickiego literackie gry z podmiotem
}

Miłosz Kłobukowski 
Pamiętnik Literacki CX, 2019, z. 1, PL ISSN 0031-0514

DOI: $10.18318 / \mathrm{pl} .2019 .1 .4$

MIŁOSZ KŁOBUKOWSKI Włocławek

TADEUSZA KONWICKIEGO LITERACKIE GRY Z PODMIOTEM

Zatrułem się [...] literaturą, udławiłem, zniszczyłem sobie życie. Ale czymś trzeba się było zagłuszać. Coś dłubać, żeby szybciej leciał czas. Aby jakoś przetrwać od poranku narodzin do wieczoru śmierci ${ }^{1}$.

Motyw literatury pełni w twórczości Tadeusza Konwickiego bardzo istotną funkcję. Książki, czy w ogóle komunikaty pisemne lub ustne, mają wpływ na życie i losy bohaterów literackich, będąc istotnym elementem świata przedstawionego wielu utworów. Sam Konwicki często mówił w wywiadach czy sylwach o miejscu sztuki słowa $\mathrm{w}$ kulturze. Wizja literatury zarówno jest zawarta implicite $\mathrm{w}$ dziele autora Pamfletu na siebie, jak i zostaje poddana tematyzacji ${ }^{2}$, a co więcej - jego sposób patrzenia na literaturę nie ulega ewolucji, tym bardziej zaś zmianom. Analizując obydwie płaszczyzny - tekstową i metatekstową - można spróbować określić spójną myśl Konwickiego dotyczącą literatury. Zagadnienie to było już wprawdzie podejmowane przez badaczy ${ }^{3}$, ale warto do niego powrócić. Niniejszy artykuł stanowi próbe „synchronicznej” rekapitulacji poglądów pisarza odnoszących się do funkcji literatury w życiu człowieka.

Stosunek do literatury w twórczości Konwickiego bywa uważany za ambiwalentny. Wczytując się $\mathrm{w}$ jego wypowiedzi zawarte $\mathrm{w}$ wywiadach, a także czytając jego sylwiczne teksty, można zauważyć dwie przeciwstawne tendencje. $Z$ jednej strony, autor Małej apokalipsy podkreśla kryzys wiary w literaturę, wynikający z kształtu współczesnej kultury; mówi o masowości działań pisarskich, o tym, że przestały one być zajęciem elitarnym, gdyż za pióro chwytają wszyscy ${ }^{4}$, wspomina

1 T. Konwicki, Pamflet na siebie. Warszawa 1995, s. 84.

2 Podobne rozróżnienie w odniesieniu do kategorii poetyki pisarza-reżysera zaproponował T. Lub elsk i (Poetyka powieści i filmów Tadeusza Konwickiego 〈na podstawie analiz utworów z lat 1947-1965). Wrocław 1984, s. 10).

3 Zob. J. Fuksiewicz, Tadeusz Konwicki. Warszawa 1967, s. 21, 54-58. - J. Walc, Tadeusza Konwickiego przedstawianie świata. Warszawa 1975. Maszynopis pracy doktorskiej. Bibl. IBL PAN, sygn. masz. 1407, s. 191, 207. - Lu be ls k i, op. cit. - P. C za pliń s k i, Tadeusz Konwicki. Poznań 1994, s. 198-203.

4 W pośpiechu. T. Konwicki rozmawia z P. Kanieckim. Wołowiec 2011, s. 20, 78. Zob. też T. Konwicki, Kalendarz i klepsydra. Warszawa 2005, s. 77:

„Janusz Grabiański [...], który był na targach książkowych tego roku we Frankfurcie nad Menem, opowiadał mi, że sam na własne oczy widział pokazane na stoiskach 70000 nowych tytułów [...]. $[\ldots]$

70000 ludzi piśmiennych, ta upiorna armia nieproszonych ochotników, chce Noblów, chce za- 
też o niechęci do czytania własnych książek ${ }^{5}$. $Z$ drugiej wszakże strony, w wielu dziełach i wywiadach manifestuje swoje uwielbienie dla literatury i wyraża pozytywny stosunek do jej „demokratyzacji”. Twierdzi, że nie należy hierarchizować dzieł literackich czy sztuki w ogóle, i przedstawia się jako człowiek biblioteki ${ }^{6}$. Podobnych paradoksalnych napięć odnaleźć można w dorobku autora więcej. Wystarczy wskazać na sąsiadujące ze sobą kategorie wierności i zdrady, tragizmu i błazeństwa, wzniosłości i przeciętności.

Przede wszystkim trzeba zaznaczyć, że literatura zawsze była dla Konwickiego nierozerwalnie związana $z$ zagadnieniem $l u d z k i e j$ podmiotowości i z konstruowaniem tejże w relacji z Innym. Przyczyniała się do tworzenia podmiotu, ale też, traktowana ze zbyt dużym namaszczeniem, stawała się źródłem kłopotów wynikających $\mathrm{z}$ trudności przystosowania się jednostki do świata, a nawet $z$ rozpadu podmiotu, łączaccego się $z$ bolesnym doświadczaniem rozziewu między tym, co realne, a tym, co wyobrażone, między wzniosłymi ideałami a „przyziemną" rzeczywistością. Literatura stwarza w świecie Konwickiego perspektywę budowania więzi międzyludzkich i jest narzędziem wzmacniania spoistości wspólnot. Równocześnie jednak współgrać może z poczuciem wykluczenia rozumianego nie tyle jako świadome odsunięcie podmiotu od innych, dokonane (czy wykreowane) przez dyskurs władzy, ale raczej jako wrażenie alienacji w świecie, kulturze, strukturach społecznych czy szerzej - w samym bycie.

\section{Wśród literackich fantazmatów - w niewoli konwencji}

Ja chcę pisać o rzeczach bolesnych, a nie produkować paskudną, wstrętną, patriotyczną literaturę! ${ }^{7}$

Dla bohaterów Konwickiego uczestnictwo w świecie zbudowanym przez literaturę nosi znamiona doświadczenia granicznego, ponieważ ma decydujący wpływ na ich życie. Staje się źródłem ideałów, podpowiada wzorce zachowań, stanowi o przyjęciu zachowań etosowych. Literatura towarzyszy wtajemniczeniu w miłość, w śmierć, jest sztuką d oj rzew a nia, a jednocześnie także sztuką dokonywania wyboru. Protagoniści dzieł Konwickiego właśnie w literaturze odnajduja matryce samorealizacji. Przeczytane fabuły warunkują ich postrzeganie rzeczywistości i determinują egzystencję. Jako przykład można wymienić chociażby postaci przynależne do pokolenia Kolumbów. Kluczową decyzję - pójścia do lasu, udziału w antysowieckiej i antyniemieckiej partyzantce - opierają one na iście Conradowskim imperatywie i tradycji przywołanej przede wszystkim za sprawą określonych lektur. Bohater Rojstów, Stanisław, wzory postępowania, „scenariusz” życia czerpie z literatury. Podobnie rzecz ma się z protagonistą Sennika wspótczesnego, który wycho-

chwytu, chce nieśmiertelności. 70000 trochę ułomnych facetów lewituje, wieszczy, wadzi się z Bogiem.

Ludzie którędy się tu przebić?"

5 W pośpiechu, s. 18.

6 Ibidem, s. 73.

7 Pisarz mówił w ten sposób o Rojstach w wywiadzie-rzece przeprowadzonym przez S. N ow icki ego [S. B e r e sia] (Pót wieku czyśćca. [Rozmowy z T. Konwickim]. Warszawa 1986, s. 45). 
wał się na Popiołach Żeromskiego, będących, o czym Konwicki nieraz wspominał, „biblią pokolenia”. To właśnie romantyczny nakaz walki w imię miłości ojczyzny stał się dla młodych ludzi z generacji pisarza najwyższą wartością i ukonstytuował ich tożsamość, wpływając na podjęcie życiowych wyborów. Tę samą regułę odnaleźć można w biografiach autora i jego rówieśników. Konwicki wzmiankował o tym w wielu miejscach, także w Pamflecie na siebie:

Byłem produktem literatury albo jej bękartem. Literatura dla mego pokolenia stanowiła narkotyk i doping. Te zadrukowane strony popychały nas na wojenną rzeź i zachęcały do prób racjonalnego urządzenia kulejącego wiecznie świata. Wstyd powiedzieć - tak było. Taki zdumiewający, despotyczny wpływ miały na nas te skromne czarne litery na kruchym białym papierze ${ }^{9}$.

Konwicki jednak, co odzwierciedla poetyka jego powieści, uwielbia ukazywać także „drugą stronę medalu”, ujawniać inne, nieoczywiste i niepopularne oblicze świata czy wręcz wchodzić w spór z samym sobą, negować, podawać w wątpliwość przyjmowane powszechnie przekonania i idee. „Rozdrapywanie ran”, polegajace na demaskacji zgubnego wpływu literatury na bezkrytycznie akceptujaccych ją naiwnych czytelników, pojawia się już w młodzieńczych, debiutanckich utworach pisarza, takich jak opowiadanie Kapral Koziotek $i$ ja, a przede wszystkim w arcydzielnych Rojstach. W pierwszym z nich Konwicki poprzez zestawienia dwóch skrajnie różnych osobowości - „twardego”, autorytarnego dowódcy i „nadwrażliwego”, wątpiącego w sens zabijania, zakompleksionego inteligenta - subtelnie ukazuje konflikt między romantycznym etosem walki za ojczyznę a prozą wojennego rzemiosła i pełną brutalności partyzancką codziennością. Pisarz komplikuje romantyczny schemat relacji między literaturą a rzeczywistością, czyniąc przesłanie utworu nieoczywistym. Wymienione opowiadanie nie mówi jedynie o nieprzystosowaniu inteligenta wychowanego na szlachetnych literackich wzorach, o wewnętrznym konflikcie osoby „która nie potrafi dobrze przeprowadzić patrolu żywnościowego, "bo przykro jakoś zabierać ostatnią kurę" ${ }^{\prime \prime}$, o rozczarowaniach żołnierza nie rozumiejącego, że „na wojnę $\mathrm{z}$ książkami się nie chodzi" ${ }^{11}$. Już w tym wczesnym utworze Konwickiego główny bohater i zarazem narrator, Ćwiok, zdaje się dostrzegać także sztuczność zachowań kaprala służbisty. Słusznie podejrzewa, że również one mogły być inspirowane literaturą.

Nieraz potem, z odległości dłuższego czasu, która mnie ośmielała zająć bardziej krytyczne stanowisko wobec kaprala Koziołka, myślałem często, czy cała postawa kaprala nie była pozą, przejętą bodaj $\mathrm{z}$ jakiejś przygodnej lektury ${ }^{12}$.

Konwicki tworzy świat, w którym wszyscy bez wyjątku coś „udają”, realizując cudzy schemat postępowania. Każdy staje się w mniejszym lub większym stopniu

T. Konwicki, Sennik wspótczesny. Warszawa 1973, s. 67.

9 Konwi cki, Pamflet na siebie, s. 80-81. Zob. też Kalendarz i klepsydra, s. 62-63. W podobnym tonie mówi Ko nwi cki (W pośpiechu, s. 40) o pierwszych fascynacjach lekturą, używając określeń takich, jak „nafaszerowanie literaturą”, „sterroryzowanie lektura”” czy „zatrucie książkami”.

10 T. Konwicki, Kapral Koziołek i ja. W: Wiatr i pyt. Teksty wybrali i do druku przygot. P. Kaniecki, T. Lubelski. Warszawa 2008, s. 11.

11 Ibidem, s. 13.

12 Ibidem, s. 10. 
„niewolnikiem” konwencji literackich, nawet młody porucznik - komendant oddziału - najwyraźniej naśladuje literackie wzorce ${ }^{13}$. $Z$ biegiem akcji okazuje się zresztą, że Ćwiok i Koziołek wcale tak bardzo się od siebie nie różnią. Obaj przecież podobnie boją się, że los właśnie ich wskaże jako osobę, której przyjdzie wykonać wyrok na niemieckich żołnierzach. Tylko kwestią czasu jest osiagnięcie przez bohatera stanu, w którym inteligent zmieni się w swój własny antynomiczny „cien” - żywiołowego, prostego, chwilami gruboskórnego, wojskowego rubachę. Prędzej czy później nadejdzie moment, w którym Ćwiok upodobni się do swego partyzanckiego alter ego, odpowiednika typu miles gloriosus - czyli Koziołka, co zostało zasugerowane przez lejtmotyw tykającego złowieszczo zegarka kaprala, jakby odmierzajacego czas do chwili ostatecznej inicjacji, czyli wykonania wyroku na jeńcu. Nieprzypadkowo w finale Ćwiok - mimo oporów moralnych i strachu - całkiem sprawnie przeprowadza egzekucję, wzorując się na schematach $\mathrm{z}$ opowiadania kaprala14, który snując swe narracje, budował w oczach kolegów mit własnej osoby. Sam zaś Koziołek okazuje słabość, zrzucając zdobyczny mundur, którym wcześniej się chwalił, i dokonując jednocześnie swoistej autokreacji. Wyraźnie więc widać, że już w debiutanckim utworze autor porusza niezwykle istotne problemy dotyczące ludzkiej podmiotowości w relacji wobec innych, której pośrednikiem staje się literatura.

W powieści Rojsty Konwicki kontynuuje te wątki, ukazując, jak ślepe zawierzenie ideałom romantycznym o proweniencji literackiej ${ }^{15}$ przeradza się w pustą grę schematami literackimi. Wiedzie do sztuczności, nieszczerości, nieautentyczności, do kiczowatego uwielbienia „romantyzmu popularnego"16 czy wręcz do histrionicznej (bezrefleksyjnie naśladowczej) teatralizacji własnych postaw i zachowań, czego symbolem w powieści stają się zużyte romantyczne „rekwizyty”, jak choćby iście grottgerowska scena pożegnania syna przez matkę $-z$ błogosławieniem krzyżem i podarowaniem ryngrafu z Matką Boską Ostrobramską. Również nieszczęśliwy wypadek śmiertelnego postrzelenia kolegi, który pozwala Konwickiemu wykorzystać kompromitujacy bohatera motyw nieposłusznej broni ${ }^{17}$, staje się pretekstem do jak mówi sam narrator i zarazem bohater - odegrania przez niego „romantycznej

Zob. ibidem, s. 13-14. Zob. też Lu bels k i, op. cit., s. 30-31.

Ćwiok oszukuje broniącego się przed pójściem „na stronę” Niemca, mówiąc, że zabiera go do dowódcy (zob. K o n w i c ki, Kapral Koziołek i ja, s. 27: „Zum Kommandant- powtórzyłem i pociagnałem go. Parabellum schowałem za siebie i bezszelestnie odbezpieczyłem”; zob. też relację Koziołka - ibidem, s. 13).

15 Zob. Nowicki [B er eś], op. cit., s. 23:

„Można powiedzieć, że żyliśmy w "wyżu" emocjonalnym, wytworzonym jeszcze przed wojną. Wydaje mi się, że pokolenia, które wchodziły w wiek szkolny i w początki dojrzałości, były przygotowane do pewnych ofiar i poświęcenia dzięki oddziaływaniu literatury patriotycznej i romantycznej”.

I dalej (s. 32):

„Myśmy odgrywali, "filmowali", swoim życiem teksty literackie!

$[\ldots]$

[...] Bo myśmy życiem realizowali literaturę, a później z tego życia raz jeszcze tworzyliśmy literaturę. [...] Oczywiście my byliśmy dziko przekarmieni literaturą. Ta literatura jednak w sporym stopniu miała stanowić o naszym morale i o tym, żeby umieć znaleźć się w tej wojnie".

16 Zob. M. J a ni o n, Tam, gdzie rojsty. Przypadek romantycznego mediumizmu. W: Projekt krytyki fantazmatycznej. Szkice o egzystencjach ludzi i duchów. Warszawa 1991, s. 154-158.

17 Zob. Lubels ki, op. cit., s. 40. 
komedii samotnego bólu"18. Nieprzypadkowo jeden $z$ bohaterów nosi pseudonim Aktor. Wyraźnie widać, że zaciaggnął się do partyzantki AK tylko ze względu na mit żołnierskiego powodzeniu u płci pięknej - nie traktuje walki poważnie, lecz jedynie odgrywa rolę żołnierza ${ }^{19}$.

W Rojstach wiele motywów to łatwe do rozpoznania kalki z literatury, mające obnażyć sztuczność i konwencjonalność świata przedstawionego. Jako przykład można wymienić wątek romansu Stanisława $z$ Celiną, będący aluzją do typowego romansu dworkowego, znanego choćby z Wiernej rzeki Żeromskiego, czy wręcz jego trawestacją ${ }^{20}$. Literackim rezonerem (być może, również sobowtórem) rozczarowanego narratora opowiadającego po latach o własnych naiwnych przeżyciach, o nieudanej inicjacji w historię staje się Bonza, dezawuujący wzniosłe wzorce, ośmieszający konwencje zachowań, ironizujący na temat wojny, przede wszystkim zaś partyzantki, która szybko traci znamiona romantycznej misji, przeistaczając się $\mathrm{w}$ bezcelowe chodzenie $\mathrm{z}$ miejsca do miejsca, przypadkowe strzelaniny, zabieranie żywności chłopom, a nawet próby ich mordowania ${ }^{21}$. Rojsty okazują się więc bolesna rozprawą ze światem romantycznych, stricte: literackich, wzorów ${ }^{22}$. Tytułowe „rojsty” zamiast oznaczać ziemię tajemniczą - magiczne „moczary nieskończoności”23, gdzie człowiek może przejść inicjację i poznać prawdy dotyczące egzystencji przekształcają się w przestrzeń zagubienia i błądzenia bohatera ${ }^{24}$.

\section{Odczarowywanie świata}

Darł z nienawiścią wielkie księgi, rozrywał na strzępy płachty gazet, kopał zapamiętale pagóry luźnych stron dymiących kurzem.

Jaka szkoda, że wszystko rozumiem. Jaka szkoda ${ }^{25}$.

Innym równie ważnym planem ludzkiej egzystencji, na który literatura zwykle ma przemożny wpływ, jest w powieściach Konwickiego dzieciństwo i in icjacja młodzieńca w dorosłość. Także w odniesieniu do tych motywów autor Sennika wspótczesnego ukazuje ambiwalentną rolę sztuki słowa. Zawierzenie jej może bowiem prowadzić zarazem do stworzenia płaszczyzny przynależności do wspólnoty, jak i do rozczarowania światem, czego owocem okazuje się bolesne podważenie

T. Konwicki, Rojsty. Warszawa 1996, s. 75.

Na temat młodzieńczych decyzji o przystapieniu do partyzantki podyktowanych zazdrością i chęcią naśladowania kolegów - w odniesieniu do doświadczeń autobiograficznych - mówi Kon wicki m.in. w ostatnim wywiadzie-rzece ( $W$ pośpiechu, s. 62-63).

Jako pierwszy zauważył to K. Wyka. Zob. Lubelski, op. cit., s. 46. - Nowicki [Ber eś], op. cit., s. 32. - Jani o n, op. cit., s. 156.

Wszystkie zasygnalizowane problemy obszernie analizuje Lubels ki (op. cit., s. 34-49).

Czapliński (op. cit., s. 18) zauważa, że „była to [...] powieść an tyedukacyjna, ukazująca zgubność nauk i konwencji ideowych wyniesionych z domu".

T. Konwicki, Kompleks polski. Warszawa 1990, s. 29. Zob. też J a ni o n, op. cit., s. 160.

Zob. N o w i c ki [B e r e ś], op. cit., s. 33. Istnieje charakterystyczne dla gwary kresowej, białoruskie przekleństwo, przywołane w powieści: „A kab to na rojsty bawlut sia w wajnu, a narod pagibajet”. Zob. też Z. K u r z o w a, Elementy kresowe wjęzyku powieści powojennej. Warszawa 1975, s. 118.

T. Ko nwicki, Dziura w niebie. Warszawa 1965, s. 344, 360. 
porządku symbolicznego. W odniesieniu do obu tych typów doświadczenia bohater buduje swoją podmiotowość. Doznaje jednocześnie pragnienia przynależności, ale też wykluczenia, poczucia obcości i osamotnienia. Jak zauważa Anna Nasalska:

Powieści Konwickiego, powstałe w różnych latach i odmienne w swoich poetykach, zdeterminowane są przez stały, obsesyjnie powtarzający się motyw konieczności samookreślenia się człowieka systematycznie pozbawionego złudzeń. [...] unaoczniają proces konfrontacji ideałów z rzeczywistością, przechodzenia od szlachetnej nieświadomości do gorzkiej samowiedzy $[\ldots]^{26}$.

Szczególnie wyraźnie motyw tego swoistego rozdarcia pisarz zrealizował w Dziurze w niebie na przykładzie losu głównego bohatera. Protagonista - Polek Krywko to dziecko samotne, nie umiejące odnaleźć swojego miejsca w otaczającej rzeczywistości. Polek trwale doznaje alienacji: $\mathrm{z}$ powodu sieroctwa, nadpobudliwości, także ubóstwa, które uniemożliwia mu spełnienie dziecięcego uczucia do bogatej, ale próżnej Wisi Puciałłówny. Jedną z ważnych osi napięć, znaczących świat przedstawiony powieści, jest podział miasteczka na dzielnice biednych i bogatych - Dolne i Górne Młyny.

Niespodziewanie chłopiec staje wobec perspektywy zmiany swojej sytuacji, a więc i porządku świata, za sprawą przekazanej przez kolegów opowieści o tajemniczych ludziach, przybyszach z zewnątrz, którzy mają zjawić się w Dolinie. W umyśle Polka nieznajomi podlegają idealizacji, są fantazmatem cudownej metamorfozy życia, budzą nadzieję na zmianę statusu społecznego, pokonanie wykluczenia, jakie dotyka wszystkich bohaterów dorastających w Dolnych Młynach. Stają się też symbolem życia aktywnego i ekspansywnego, które próbuje wieść wiecznie nieposłuszny i ruchliwy chłopiec. Oczekiwani przybysze uosabiają w jego wyobraźni świat istniejący poza zamkniętą enklawą Doliny wileńskiej, kojarzą się z możliwością wyjazdu, opuszczenia tej po części idyllicznej, a po części nieszczęśliwej krainy dzieciństwa. Mówiąc krótko, są dla Polka figurami dorosłości, która zawiera w sobie obietnicę szczęścia. We wstrząsającym finale utworu okazuje się jednak, iż mający przybyć do Doliny ludzie zostali zmyśleni na potrzeby dziecięcej zabawy rówieśników Polka. Odkrycie to sprawia, że chłopiec doznaje bolesnej „inicjacji”, polegającej na zderzeniu naiwnych, choć szlachetnych marzeń z rzeczywistością, czyli na rozczarowaniu. Wszystko było tylko ułudną, oszukańczą narracją opartą na schematach znanych $z$ literatury dziecięcej czy przygodowej ${ }^{27}$. Fantazmat wyczerpuje się w funkcji opowieści, na której tle tym wyraźniej i boleśniej obnażona zostaje dziecięca prostoduszność chłopca.

- A co z tymi, na których czekamy?

Łapa nie odpowiedział, zamarły w bezruchu.

- Słyszysz? Główny Marszałku? Czekaliśmy na ludzi, którzy mają przyjść do naszej doliny.

Łapa nie podnosząc głowy rzekł cicho:

- To była zabawa. Nie ma żadnych ludzi prócz nas.

- Łżesz! - poderwał się Polek. - Muszą być, to niemożliwe, żeby nie było.

- Dziecko jesteś? Przecież nikt w to nie wierzył ${ }^{28}$. 
Obłąkany fantazmatyczną idea Polek penetruje starą, opuszczoną papiernię w poszukiwaniu Tajemnicy. Tym, co znajduje, jest porzucona, zapomniana „biblioteka kresowa”, symbolizująca ekumeniczny, pluralistyczny mit Kresów. Wymowa tego obrazu jest ambiwalentna. $Z$ jednej strony, odczytać go możemy jako sygnał upadku kultury, która okazała swą niemoc w zderzeniu $z$ historią. W wyniku przemian historycznych wielokulturowe pogranicze, znaczone rodzącymi się nacjonalizmami, utraciło swój arkadyjski rys. $Z$ drugiej wszakże strony, rozpoznawana strata ma swoich autorów. Oskarżenie skierowane jest do tych, którzy nie skorzystali z nauk zawartych w różnojęzycznych tomach. Polek nieprzypadkowo odkrywa, że ich karty nie zostały nawet porozcinane.

Leżą [...] [książki] w stertach na wykrzywionych od starości regałach, pokrywają grubą warstwą ziemię, piętrzą się w wielkich kopach. Są to książki polskie, rosyjskie, żydowskie i litewskie. Książki wszystkich narodowości zamieszkujących tę ziemię. Większość z nich nie ma okładek, rozsypują się jak talie pożółkłych kart. Można podnieść którąś, odczytać w niej stosowną sentencję. Zawarły bowiem w sobie wszystkie myśli, pragnienia i nadzieje swego czasu. Jedne mają rogi czarne i spuchłe od palców życzliwych czytelników, innych nikt nawet nie rozciął. Leżą tu teraz jednakowo zapomniane przez żarna papierni ${ }^{29}$.

Jak zauważa Dorota Siwor, opisane przez Konwickiego zdarzenie to „obraz klęski totalnej, klęski całej kultury i całej tradycji”:

Najistotniejszy wydaje się sens symboliczny właśnie, który wynika z odczytania całości jako swoistej paraboli, opowieści o uniwersalnym losie człowieka rozdartego pomiędzy ideałem, którym jest pragnienie stanu szczęścia i harmonii, a zasadą świata, która ich realizację uniemożliwia. Podjęcie takiego tematu oraz sposób jego ujmowania wyraźnie wskazuja na nawiązanie do koncepcji romantycznych ${ }^{30}$.

Konwicki mówi metaforycznie nie tylko o rozczarowaniu i bolesnym wyzbywaniu się złudzeń. Mówi także - a może nawet przede wszystkim - o literaturze i jej roli. Przedstawiony tu obraz „klęski całej kultury i całej tradycji” jest jednocześnie wielką metafora porażki literatury. Tej samej literatury, która od starożytności postrzegana była w cywilizacji śródziemnomorskiej jako przekaz doświadczenia, jako składnik budujący communitas. Działo się tak od chwili, gdy aojdowie recytowali poematy Homera w niepiśmiennych zbiorowościach, dając świadectwo własnego istnienia w konkretnym czasie i rzeczywistości społeczno-kulturowej w literaturze widzieli znak istnienia ludzkiej podmiotowości ${ }^{31}$. Konwicki podważa w przywołanej przed chwila scenie całą europejską tradycję, której „emblematem” mógłby stać się Horacjański motyw „Exegi monumentum aere perennius / [...] / Non omnis moriar [...]"32. Metafora śmierci literatury, która - zapomniana - nie

D. Siw or, Między infantylizmem a dojrzałościa, czyli o dzieciństwie $w$ powieściach Tadeusza Konwickiego. W zb.: Kompleks Konwicki. Materiaty z sesji naukowej zorganizowanej $w$ dniach 27-29 października 2009 roku przez Wydział Zarzadzania i Komunikacji Społecznej UJ oraz Wydziat Polonistyki UJ. Red. A. Fiut, T. Lubelski, J. Momro, A. Morstin-Popławska. Kraków 2010, s. 114, 115.

31 Zob. A. St off, Ja, autor. O funkcjach sygnatur $w$ literaturze wspótczesnej. W zb.: Ja, autor. Sytuacja podmiotu w polskiej literaturze wspótczesnej. Red. D. Ś n i eż k o. Warszawa 1996. - M. C z e rm in s k a, Hipoteza autorstwa. (O podmiocie dziet wszystkich jednego autora). W zb.: jw. 
pelni przypisanych jej funkcji przekazywania prawd życiowych, wartości, doświadczeń, zabezpieczania śladów ludzkiego losu, literatury, która nie ma mocy budowania kultury, staje się symboliczną antycypacją śmierci mitu Kresów. Pogranicza ukazywanego nieraz jako kraina otwartości, tolerancji i poszanowania Inności (nieprzypadkowo w papierni są książki „wszystkich narodowości zamieszkujących tę ziemię"). Obraz ten interpretować można też jako zapowiedź (do pewnego stopnia proroczą ${ }^{33}$ ) odejścia od rozumienia funkcji tradycji literackiej jako przestrzeni budowania więzi międzyludzkich i przepowiednię swoistego unicestwiania podmiotowości ${ }^{34}$.

Co więcej, Konwicki w scenie $z$ papierni rozwija myśl o oszustwie, jakiego dopuszcza się literatura, o nieuprawnionej manipulacji podmiotu dokonującej się z jej udziałem. Symboliczne znaczenie ma tu finał wizyty w budynku. Przytłoczenie i uwięzienie Polka przez zawalone regały z książkami oznacza - jak wyjaśniał sam pisarz - zawłaszczenie umysłu przez uwznioślony świat idei, który tak naprawdę nie istnieje. Konwicki wskazuje tym samym na istnienie przemocy, jaką fantazmat wywiera na to, co realne. Przestrzega przed bagatelizowaniem czy wręcz niezauważaniem przemocy symbolicznej, która może prowadzić do niefortunnych (z perspektywy czasu) wyborów życiowych.

Tytułowa „dziura w niebie” oznacza katastrofę w percypowaniu świata przez bohatera. Symbolizuje dziecięce rozczarowanie złudnymi (lub płonnymi) nadziejami, co przekłada się na poczucie bezsensu życia jako takiego. Podobnie reinterpretacji w dziele Konwickiego ulega typowo literacki motyw nieznajomego przybysza, którego w powieści spotyka Polek. Wbrew oczekiwaniom opartym na znajomości konwencji literackich, jakimi moga kierować się i bohater, i czytelnik, obcy nie odkrywa przed Polkiem żadnego sekretu będącego obietnicą szczęścia. Wręcz odwrotnie: za jego sprawą chłopiec, jako świadek samobójstwa mężczyzny, zostaje wtajemniczony w śmierć. Konwicki nie po raz pierwszy wykorzystuje w tym wątku motyw presji słowa pisanego. Polek znajduje w walizce nieznajomego manuskrypt, który stanowi zapis życia człowieka nieszczęśliwego, wykluczonego z ludzkiej zbiorowości, zaznającego obcości egzystencjalnej w najgłębszym, ontologicznym znaczeniu. Człowieka osamotnionego, rozczarowanego światem i nie umiejącego skonstruować spójnej podmiotowości.

Przedsiębiorę daleką podróż. Powracam tam, skąd kiedyś wyszedłem albo raczej - skąd mnie wygnano. Wyruszam - nie wiem po co. Może, aby ogrzać oczy krajobrazem śniącym się każdej nocy zimowej, może, by spotkać człowieka, którego nie mogę zapomnieć. A może - by umrzeć, nawet choćby nie naprawdę.

$[\ldots]$

Pięknie - aż boli. [...] Dorośli przychodzą tam, aby umrzeć35

Szczególnie interesujące okazuje się rozwiązanie, w którym Konwicki sugeruje, że samobójca może być alter ego Polka. Lektura rękopisu pozwala rozpoznać w nim

ski. Wrocław 1967, s. 137 (przeł. L. Ryd el). BN II 25. Por. przekład A. Waży ka w: H o r a cy, Dwadzieścia dwie ody. Oprac. S. S ta b ryła. Wrocław 2004, s. 63. BN II 232. 
sobowtóra bohatera - osobę, której udaje się wprawdzie zrealizować skryte marzenie chłopca o ucieczce z Doliny, ale która, podobnie jak główny bohater, doznaje poczucia obcości, także w dorosłym życiu. Doświadczenie tej powtórnej alienacji, staje się kolejnym źródłem rozczarowania i przyczynia się do (być może, wyobrażonego) powrotu do Doliny dzieciństwa i do samobójstwa ${ }^{36}$. W ten sposób Konwicki ukazuje tragiczny wariant ludzkiej egzystencji, wedle którego człowiek jawi się jako wygnaniec $z$ urojonego Raju; jako osoba, która nieodmiennie lokuje zapewniajacy szczęście, ale nieosiągalny przedmiot pożądania poza swoim światem, przez co nieuchronnie doznaje poczucia obcości ${ }^{37}$. Także i tu odnaleźć można wpływ rozmaitych narracji, czyli po prostu literatury, która z przywiązanych do niej bohaterów Konwickiego czyni nieprzystosowanych marzycieli, tęskniących do nieosiaggalnego, minionego. Nie potrafią oni bowiem zrealizować ideałów w dostępnym im otoczeniu. Wiedzę demistyfikującą dorosłe życie poza Doliną, negatywne wtajemniczenie w egzystencję, chłopiec czerpie właśnie z przekazu pisanego - z pamiętnika przybysza-samobójcy.

Podobne notatki dotyczące życia jakiegoś biednego i rozczarowanego człowieka znajduje protagonista Nic albo nic w ubikacji w pociagu; po lekturze wrzuca je do muszli klozetowej ${ }^{38}$. Bohater Sennika współczesnego - Paweł - natrafia na stare, zapomniane dokumenty, pochodzące jeszcze $z$ czasów wojny, które jednak, jak odkrywa, stanowią tylko „fałszywy ślad istnienia” 39 .

w dolnej szufladzie odkryłem sporą garść starych szpargałów. Oglądałem zżółkłe dokumenty czyjegoś losu w ostatniej wojnie. Były tu auswajsy zapomnianych dawno instytucji okupacyjnych, karty arbeitsamtu, zwolnienia lekarskie naszpikowane łacińskimi diagnozami, w których często powtarzało się złowróżbne jak zimowy kwiat słowo - tuberkuloza. $Z$ dowodu osobistego spojrzała na mnie młoda twarz, bez wyrazu, nijaka, sympatyczna jedynie swoją młodością. Odczytywałem to nazwisko, które na pewno było nieprawdziwe, przyglądałem się pieczęciom, bez wątpienia podrobionym, i starałem się odtworzyć w myślach tok życia człowieka, co zostawił po sobie, jak garść popiołu, ten fałszywy ślad istnienia.

- Pan tak po ciemku? - usłyszałem za sobą głos pani Malwiny.

Zatrzasnąłem wstydliwie szufladę.

- Proszę bardzo, proszę się nie krępować. To nie nasze te papiery.

- A czyje?

- Niczyje. Po nieznanym człowieku zostały ${ }^{40}$.

Witold, jako dorosły już bohater Kroniki wypadków miłosnych, poszukuje wśród starych szpargałów zdjęcia ojca, gdyż nie może odnaleźć w pamięci jego twarzy ${ }^{41}$. Protagoniści opowiadania Kilka dni wojny, o której nie wiadomo, czy była znajdują karteczkę z personaliami jakiegoś nieznanego człowieka. Staje się ona jedynym

Sam Konwicki (W pośpiechu, s. 10) uznawał ten chwyt literacki za punkt zwrotny w krystalizowaniu się jego własnej poetyki: „tam umieściłem - to jest tylko moja sprawa - dziennik wisielca. I to był punkt zwrotny w mojej karierze, coś takiego się we mnie stało, że zacząłem pisać po swojemu”. Zob. też s. 217, 284. Jak zauważa Walc (op. cit., s. 100), „Arkadii nie tylko nie było, ale nie ma i nie będzie. Można najwyżej tworzyć ją we wspomnieniu, które dawne miejsca i zdarzenia idealizuje [...]".

T. Konwi c ki, Nic albo nic. Warszawa 1973, s. 181-198.

Ko nwicki, Sennik wspótczesny, s. 98.

Ibidem.

41 T. Konwi cki, Kronika wypadków miłosnych. Warszawa 1974, s. 159-160. 
śladem istnienia tej osoby ${ }^{42}$. Powracający motyw tekstu w tekście ${ }^{43}$ można nazwać rękopisem zawieszonym w próżni ${ }^{44}$. Warto podkreślić, że za każdym razem pojawienie się takiego paraliterackiego przekazu związane jest w świecie przedstawionym fabuł Konwickiego z przeżyciem inicjacji bohatera, która okazuje się inicjacją nieudana. Słowo pisane pozostaje niemal zawsze znakiem jakiejś zapomnianej podmiotowości, choć z drugiej strony - otwiera przestrzeń wspólnego odczuwania, więzi między protagonistami a autorami rękopisów.

Schemat „negatywnej inicjacji” powtarza Konwicki w różnych wariantach, zwłaszcza w powieściach dziecięcych i wspomnieniowych. Szczególnie istotna wydaje się pod tym względem Kronika wypadków miłosnych, w której dojrzewający bohater Witold, nazwany przez Marię Janion nowym Gustawem literatury polskiej ${ }^{45}$, przeżywa w sposób prawdziwie romantyczny wielka, zakazana miłość do panny z wyższej warstwy społecznej. Można powiedzieć, iż powielając romantyczną konwencję literacka, Konwicki realizuje wzór podsuwany przez znakomitego poprzednika. Młodzi kochankowie, zgodnie $z$ paradygmatem romantycznym, targną się nawet na własne życie. Próba samobójcza skończy się jednak niepowodzeniem, a odzyskujący przytomność Wicio nie będzie do końca pewien, czy wielki i namiętny romans nie był tylko snem. Bohater odkryje też literacką proweniencję realizowanych przez siebie wzorców zachowań. To właśnie on wypowie znamienne słowa: „Obżarliśmy się literatura. Jesteśmy pokoleniem zatrutym przez fikcję" ${ }^{46}$. W tym samym czasie dorosły Witold, znów alter ego bohatera, popełni wyimaginowane samobójstwo, gdyż realność przyniesie mu tylko poczucie nieszczęścia i wykluczenia. Ostatecznie umrze w samotności na raka żołądka. Zdaniem Nasalskiej, tak charakterystyczna dla Konwickiego kompromitacja romantycznego, literackiego wzorca miłości jest najwyraźniejszym odbiciem obcości odczuwanej przez człowieka oraz reifikacji stosunków międzyludzkich ${ }^{47}$.

\section{Przymus opowiadania}

Chciałem zostawić ślad, monogram na ścianie, nie wiem, dla kogo, i nie wiem, po co. Ale odczuwałem potrzebę ${ }^{48}$.

Chociaż fascynacja literaturą sprowadza na bohaterów Konwickiego niebezpieczeń-

Zob. T. Ko n w i c ki, Kilka dni wojny, o której nie wiadomo, czy była. Lublin 2001, s. 43: „Schował przybory toaletowe, przy okazji znalazłszy zmiętą karteczkę $\mathrm{z}$ czyimś nazwiskiem oraz adresem. Kartkę ze znakiem rozpoznawczym czyjegoś istnienia w małym świecie, którego już nie ma i nigdy nie będzie". Opowiadanie pierwotnie ukazało się jako fragment sylwy Zorze wieczorne (Warszawa 1991, s. 88-179). go. Warszawa 2014, s. 233) w odniesieniu do czytania przez Helenę Konwicką, bohaterkę Bohini, niepokojących wypisów z różnych dzieł poczynionych przez jej ojca, Michała. Badacz interpretuje nawet Sennik wspótczesny jako drugą część rękopisu wisielca z Dziury $w$ niebie - zob. P. Kan i e c ki, Wniebowstapienia Konwickiego. Warszawa 2013, s. 78.

Zob. Janion, op. cit., s. 168.

K o n w i c ki, Kronika wypadków miłosnych, s. 225.

$\mathrm{N}$ a s a l s k a, op. cit., s. 244-245.

W pośpiechu, s. 21. 
stwo bycia oszukanym, popadnięcia w nieautentyczność i pozór ${ }^{49}$, mimo iż w świecie ogołoconym przez wojnę $z$ tradycyjnych wartości literatura przestaje pełnić swoje aksjologiczne funkcje (a wiąże się to ze zmiana paradygmatu antropologicznego), czego krańcowym znakiem sa narodziny postmodernizmu ${ }^{50}$, pozostaje ona dla autora Rojstów jedynym sposobem radzenia sobie z odrzuceniem, wykluczeniem, samotnością.

Tadeusz Lubelski wskazywał w swojej monografii, że bohaterowie Konwickiego, odbywając wyobrażone wędrówki po krainach własnej, zapamiętanej przeszłości, mistyfikuja je, posługując się kliszami literackimi ${ }^{51}$. Wędrowanie to dla Konwickiego metafora pisania, czyli zmyślania i mitologizowania różnych wariantów własnego losu, stanowiąca zarazem remedium na zło świata. Najbardziej wyrazistym przykładem terapeutycznej funkcji literatury może być finał Zwierzoczłekoupiora. Czytelnik docierając do ostatnich kart powieści dowiaduje się, że cały świat przedstawiony został wymyślony przez umierającego na białaczkę samotnego chłopca.

Nie gniewajcie się, że opowiedziałem wam taką zupełnie nieprawdziwą historię. Ale ja naprawdę chciałbym się kochać w takiej dziewczynie jak Majka czy choćby Ewa, chciałbym czasem wagarować, chciałbym zagrać w filmie o podróżach międzyplanetarnych [...].

Opowiadałem tę nieprawdziwą, zmyśloną historię właściwie sobie samemu. Bo chciałem się troszeczkę uwolnić od bólu, strachu i złych myśli. Przyjemnie jest uwalniać się i być wolnym.

$[\ldots]$

Najcudowniejsze, że pohasałem sobie trochę na swobodzie. Życzę wam tego samego. Żebyśmy tylko zdrowi byli. Żebyśmy tylko... [wolni byli $]^{52}$.

Terapeutyczny wymiar pisania, a nawet przywiązanie do swoistego eskapizmu literackiego, wyraził Konwicki w Senniku współczesnym. Jego bohater - Ildefons Korsak - zapisuje w kolejnych zeszytach prozę fantastyczną, przedstawiając swoje

Konwicki wielokrotnie wykorzystuje motyw udawania czy wręcz pozerstwa. Doskonałym przykładem jest chociażby postać Kowalskiego-Malinowskiego z filmu Salto. Zob. Lube 1s ki, op. cit., rozdz. 9: Artysta i odbiorcy.

50 Z. B a u ma n (Nowoczesność i Zagłada. Przeł. T. Ku n z. Kraków 2009) stawia tezę, że Holokaust okazał się skrajnym, krańcowym punktem dojścia nowoczesności rozumianej jako projekt kulturowy. Ponowoczesność jest w swej naturze polifoniczna. Walc (op. cit., s. 77) zauważa, że narratorzy i bohaterowie Konwickiego w utworach popaździernikowych „odwracają się od obcego słowa”, co jest skutkiem rozczarowania autorytetami, które okazały się fałszywe, mylące, a co zarazem doprowadziło pisarza do przekonania, że „prawdę o świecie można mówić tylko w imieniu jednostki, w imieniu siebie samego i dlatego tak kategorycznie podporządkował przestawiany świat swoim narratorom”. I dalej (s. 79): „U Konwickiego sytuacja poznawcza jednostki świadomej swoich ograniczeń jest na tyle skomplikowana, że nie ma mowy o wychodzeniu poza tę jednostkę, o nastawieniu się na cudze słowo. Dlatego właśnie Konwicki tworzy powieści m o n o f o n i c zne, opowiadane przez narratorów świadomych polifoniczności i symultaniczności świata”. Zob. też A rlt, op. cit., s. 32, 36 - badaczka stawia tezę, że rozszczepowi struktur narracyjnych w dziełach Konwickiego towarzyszy zdekonstruowana, pęknięta, nieharmonijna kondycja bohatera-narratora lub samego bohatera; zwielokrotnionej jaźni towarzyszy zwielokrotniona narracja.

51 L u be ls k i, op. cit., s. 151-152. W alc (op. cit., s. 7, 14-16) wcześniej wskazywał, że „świat przedstawiony jest elementem bohatera”. Wymieniał także świadomość kulturową (występowanie aluzji, toposów, odniesień do kultury europejskiej, zwłaszcza tradycji literackiej) jako cechę myślenia bohatera-narratora.

52 T. Konwi cki, Zwierzoczłekoupiór. Warszawa 1969, s. 276-277. Ostatnie słowa zostały usunięte przez cenzurę. 
bolesne doświadczenie w przekonaniu, że zostawia ślad, który może kiedyś dla kogoś okaże się ważny. Sztuka słowa, związana z autobiograficznym wymiarem jednostkowej egzystencji, winna według Konwickiego odkrywać wiedzę o człowieku rozumianym jako indywiduum, być śladem czyjegoś zawsze indywidualnego i niepowtarzalnego losu ${ }^{53}$. Także w Nic albo nic Konwicki zawarł scenę wieczoru autorskiego, którą można odczytywać jako manifest odwrotu od realizmu. Sztuka słowa nie ma być według pisarza prostym opowiedzeniem świata, gdyż jako taka nie wykorzystywałaby w pełni właściwego sobie potencjału terapeutycznego ${ }^{54}$. Odwołując się do metaforyki zaproponowanej przez Meyera Howarda Abramsa, powiedzieć by można, że powinna być raczej lampą oświetlającą ciemne głębie umysłu, duszy podmiotu niż zwierciadłem ${ }^{55}$. Sam Konwicki wielokrotnie podkreślał w wypowiedziach metaliterackich swój dystans do literatury realistycznej ${ }^{56}$.

Praca wyobraźni, która tworzy różne scenariusze, operując materiałem biograficznym i quasi-biograficznym, ma więc charakter kreacyjny i równocześnie katartyczny. W świecie grożącym wykluczeniem albo destrukcją (obsesyjnie powracające motywy samobójstwa i wykonywania wyroku), w którym negowana jest silna ludzka podmiotowość, literatura - choć niebezpieczna i niosąca groźbę nietrafnego zawierzenia, mylnego rozpoznania, manipulacji - okazuje się jedynym możliwym środkiem ocalenia $^{57}$. Takich właśnie wartości szukają bohaterowie Konwickiego. Sens i ratunek kryje się w samej czynności opowiadania, czyli budowania narracyjnej tożsamości i jej terapeutycznej funkcji ${ }^{58}$. Dla pisarza pamięć, wyobraźnia i zdolność snucia narracji są ze sobą ściśle połączone, stanowiąc fundament podmiotowości ${ }^{59}$.

Chociaż, jak wspominaliśmy, Konwicki nieraz kompromituje zwyczaj prostego naśladowania wzorów literackich, wskazując, że taka postawa nosi rysy histrionizmu, błazeństwa, sztuczności, że zasługuje na ironiczne czy autoironiczne gesty odrzucenia i deziluzji, to jednocześnie pisarz potwierdza, iż podobna nieufność nie przekreśla bynajmniej roli literatury w życiu człowieka. O ile bowiem bezkrytyczne przyjmowanie wzorców literackich może prowadzić do rozczarowania światem i poczucia obcości egzystencjalnej, o tyle literatura jako taka pełni funkcję swoistego

Zob. Ka ni e c ki, Wniebowstapienia Konwickiego, s. 94-95.

Zob. W a lc, op. cit., s. 23. Walc obszernie mówi o motywie rozczarowania pisarza-realisty, o nieufności wobec możliwości epiki, która jedynie opisuje rzeczywistość. Zob. też N a s a ls k a, op. cit., s. 251 - badaczka interpretuje tę scenę jako ukazującą konwencjonalizację sztuki, co prowadzi do dystansu między autorem a odbiorcą, jak również nie pozwala na dostarczanie autentycznych przeżyć.

M. H. Abrams, Zwierciadło i lampa. Romantyczna teoria poezji a tradycja krytycznoliteracka. Przeł. M. B. F e dewi cz. Gdańsk 2003.

Zob. W pośpiechu, s. 10-11, 16. Stosunek pisarza do realizmu wcale nie jest tak jednoznaczny, jakby się mogło wydawać, gdyż niejednokrotnie sam określał się mianem realisty (skłonnego do czasowego łamania tej konwencji), a także nazywał realistycznymi np. Mickiewiczowskie Dziady zob. Nowicki [B ereś], op. cit., s. 80, 89, 152.

Zob. Walc, op. cit., s. 37.

Zob. J. Kor dy s, Kategorie antropologiczne i tożsamość narracyjna. Szkice z pogranicza neurosemiotyki i historii kultury. Kraków 2006, s. 217-243. Badacz wskazuje na kompetencję narracyjną jako obszar autonomii wolny od wpływów genetycznych na psychikę, za pomocą którego człowiek wyraża indywidualność (ibidem, s. 235).

Zob. T. Konwicki, Nowy Świat i okolice. Warszawa 1990, s. 134: „Gdzie się kończy pamięć, a gdzie zaczyna rutyna literacka. Wszystko jedno. Albo raczej wszystko grą wyobraźni”. 
remedium na stan alienacji, pozwalając na konstruowanie „ja” i podtrzymujacc wzorce podmiotowości. Trzeba zaznaczyć, że nie jest to naiwne, bezrefleksyjne naśladownictwo konwencji, ale dojrzałe, odbywające się już po procesie „odczarowania” świata, poszukiwanie przez podmiot sfer przynależności. Literatura okazuje się receptą na wykluczenie, bo sama staje się enklawą dla ludzi osamotnionych i pozbawionych własnego miejsca.

Literatura oferuje zatem według Konwickiego możliwość przeżycia katharsis. Pisarz w wypowiedziach metaartystycznych często odwoływał się do psychodramy, do której miał dążyć w swoich filmach, a także w samym procesie tworzenia literatury - porównywanym do stanu kataleptycznego ${ }^{60}$. Twórczość jest „miejscem”, gdzie człowiek wyobcowany ma szansę odnaleźć i zbudować substytut „swojego” świata, będący podstawą własnej, silnej podmiotowości. Literatura jest „obszarem”, w którym na chwilę można przezwyciężyć obcość ${ }^{61}$ :

Sztuka to jest nasz jedyny bagaż i majątek. Padam plackiem wobec cywilizacji, biję czołem przed nauką i podziwiam wiele innych rzeczy, ale jedyne, czegośmy się naprawdę dorobili, to jest sztuka. Ona właśnie jest zapisem naszej obecności w galaktyce i wszechświecie ${ }^{62}$.

Ja usiłuję zracjonalizować, sprowadzić do intelektualnych form te wszystkie niepokoje i rozpacze, które ludzi męczą. I jeśli ktoś to czyta i widzi, że inny człowiek podobnie się szamocze, to dla niego znaczy, że nie jest najgorzej, bo nie jest sam. Że jesteśmy razem. Czy w tak zwanym świeckim życiu wiele więcej możemy zaproponować bliźniemu? ${ }^{63}$

\section{Spotkania z Innym}

Nie ma literatury bez czytelnika. Jaki czytelnik - taka literatura $^{64}$.

Wizja człowieka, jaka przedstawia Konwicki, wydaje się paradoksalna. Podmiot rozdarty jest między pragnieniem przynależności do grupy a poczuciem alienacji, między naiwną wiarą a rozczarowaniem, między pesymizmem a próbą kompensacji, podejmowaną w oparciu o literackie wyobrażenia świata. W literaturze odnajdują bohaterowie Konwickiego drogę stanowiąca jedyne, oprócz samobójstwa, rozwiązanie dla świadków historii XX wieku.

Zob. W pośpiechu, s. 88: „to jest ciekawostka biologiczna, że ten proceder pisania był rodzajem takiego minikataklizmu dla mnie, dla organizmu, dla mojego samopoczucia”. Zob. też Pamflet na siebie, s. 81: „Pisanie to były czary, jakaś tajemnicza liturgia, a może nawet pewna forma świętokradztwa”. W a lc (op. cit., s. 24-25) wyróżnia dwie funkcje narracji snutych przez protagonistów Konwickiego - profetyczną i ludyczną, które opalizują, i jedynie od czytelnika zależy, jaka perspektywa odbioru dzieła zyska rangę nadrzędną. Badacz wskazuje oczywiście również na funkcję kompensacyjną (ibidem, s. 29-30).

62 Nowicki [Bereś], op. cit., s. 147.

63 Jesteśmy wcią̇ tacy sami. Z T. Konw i cki m rozmawia T. S o b o lew s ki. „Litteraria Copernicana” 2008, nr 1, s. 205. Zob. też inne wypowiedzi T. Konwickiego o literaturze: Wschody i zachody księżyca. Warszawa 1990, s. 5-7, 15-16, 50-52, 83-84, 97-98, 117-118, 133-135, 162-165, 236-237, 249-250, 346, 359; Nowy Świat i okolice, s. 5-7, 10, 31-32, 67-68, 134, 190-193, 204-206, 220, 227; Zorze wieczorne, s. 5-6, 7, 14-17, 26-29, 72-75, 84-85, 186, 199-202, 213-214, 251-256; Pamflet na siebie, s. 63, 79-91; Pamiętam, że było goraco. Rozmowy przeprowadzili K. Bielas, J. Szczerba. Kraków 2001, s. 147, 182-184, 194-196; Kalendarz i klepsydra, s. 62-63, 84-85, 133-136, 182-183, 210, 259-260, 263-264, 333-337.

Ko nwi cki, Nowy Świat i okolice, s. 32. 
Warto ponownie zwrócić uwagę na niezwykle interesujący motyw rękopisu, tekstu w tekście. Pełni on ważną funkcję w konstruowaniu właściwej dla Konwickiego wizji antropologicznej, a także sposobu rozumienia filozoficznych funkcji literatury. Dla Konwickiego tekst pisany staje się śladem ludzkiej obecności, manifestacja jednostkowej podmiotowości, co pozwala powiązać autora Rojstów z europejską tradycją metafizyki obecności, pojęciem indywidualności dzieła, literatury rozumianej jako twór pochodny wobec osoby i jej wolnego, świadomego aktu kreacji65.

Jak wspominaliśmy, przekaz literacki ma ogromny wpływ na życie i wybory bohaterów Konwickiego. Co więcej, teksty, będące śladami realnej, ludzkiej obecności, pozwalają postaciom z jego dzieł uświadomić sobie istnienie świata odmiennego, okazuja się elementem ontologicznie obcym. Jako takie, destabilizując porządek rzeczywistości, wymuszają dialog z tym, co inne, prowadzą do spotkania z tym, co obce, w jednostkowym, niepowtarzalnym zdarzeniu zapośredniczonym przez język. Czyż literatura nie jest przede wszystkim kontaktem z drugim człowiekiem - zwłaszcza z czytelnikiem? „Nie ma literatury bez czytelnika” - mówił, bez lęku przed posądzeniem o truizm, pisarz. Konwicki wielokrotnie wskazywał na „dialogiczny” charakter literatury. Zwracał również uwagę na rolę zaangażowania odbiorcy w proces budowania relacji, więzi z autorem. Nazywał czytelnika swoim „powiernikiem”66, potrzebę zaś ekspresji artystycznej tłumaczył chęcią powiedzenia czegoś innej osobie ${ }^{67}$.

Konwicki często akcentował personalistyczny wymiar własnej twórczości, a zarazem waloryzował autentyzm jako cechę dystynktywną swego pisarstwa. Podkreślał wage naturalności, brak zapośredniczenia aktu komunikacji w dyskursach filozoficznych i literaturoznawczych. Condicio sine qua non chwycenia za pióro było doświadczenie, wyrażane spontanicznie i emocjonalnie ${ }^{68} . Z$ drugiej jednak strony, na literacki autentyzm nakłada się w powieściach Konwickiego płaszczyzna gry z literaturą i w literaturę, która sprawia, że postawa pisarza okazuje się paradoksalna, oscyluje między dążeniem do prawdy a fabularyzowaniem, tendencją autobiograficzną i autokreacyjną. Pragnienie wyrażenia prawdziwego autorskiego „ja” staje się równie silne jak żywioł zmyślenia i gry z czytelnikiem. Jerzy Jarzębski zauważył, że w prozie drugiej połowy XX wieku pojawiła się grupa utworów (wśród nich badacz wymienia m.in. Mała apokalipsę, Kompleks polski, Kalendarz i klepsydrę), których świat przedstawiony ma niejasny status ontologiczny, przypominający hybrydę wymagająca wsparcia w autotematycznych komentarzach samego autora ${ }^{69}$. W książkach tych nie sposób jednoznacznie oddzielić prawdy od zmyślenia, autentyzmu od mitologizowania.

„autentyk" [...] stał się [...] obiektem gry między autorem i czytelnikiem, w której idzie już nie tyle o „zgodność z rzeczywistościa”, ile o „,szczerość”, „Zmyślenie” etc., tzn. kategorie prawdy i fałszu pojawiają się zawsze w ścisłym związku z osobą, której sąd podlega kwalifikacji. [...]

Zob. np. A. S t off, Przemiany funkcji literatury $w$ świecie wspótczesnym a jej zobowiazania wobec człowieka. W zb.: U progu trzeciego tysiaclecia. Red. A. Bi a ł e k a, J. J a d a c ki. Warszawa 2001. 
$[\ldots]$

[...] wytwarza się sytuacja obustronnej korozji wartości: podejrzane stają się zarówno same zdarzenia - materiał utworu, jak i pisarskie rzemiosło fabulatora. Swoją godność odzyskać mogá jedynie wspierając się wzajemnie: fakty nabierają wagi poprzez literackie opracowanie - fabularyzacja zachowuje sens i wartość tylko oddając się w służbę „autentykowi”. Stąd bierze się charakterystyczna niepewność, którą odczuwamy w zetknięciu z tego typu książkami; wszystko w nich wydaje się podlegać zakwestionowaniu [...]. [...] utwór [...] staje się [...] za d a n i e m dla autora i czytelnika, którzy wspólnie zajmują się wyłuskaniem sensownego planu z nadmiarowego wobec takich usiłowań świata ${ }^{70}$.

Równocześnie tworzenie literatury to dla autora Bohini przede wszystkim wynik zaspokajania wrodzonych człowiekowi potrzeb estetycznych, tęsknoty za nieśmiertelnością, budowania własnej spuścizny, ale i otwierania się na to, co inne i obce. Konwickiemu bliższe jest pytanie o uniwersalne prawdy dotyczące człowieka niż narcystyczne eksplorowanie własnej podmiotowości twórczej i języka ${ }^{71}$. W wywiadzie udzielonym Przemysławowi Kanieckiemu pisarz mówił:

Mógłby pan zadać jedno pytanie: to po co pan pisał i robił filmy? Otóż to jest ciekawa sprawa - że ja przy swoim sceptycyzmie i bardzo ograniczonych pretensjach do życia nie wiem, po co to robiłem, ale chciałem zrobić. Chciałem zostawić ślad, monogram na ścianie, nie wiem, dla kogo i nie wiem, po co. Ale odczuwałem potrzebę. Co się też wiązało z moją jakby biologią literacką: że ja nie miałem warsztatu przygotowanego naukowo, nie miałem planów na lata. Raczej, wstyd powiedzieć, bo to jest okropne, do czego się przyznaję, raczej kierowała mną spontaniczność, coś chciałem powiedzieć, coś chciałem zrobić ${ }^{72}$.

Sposób rozumienia dzieła literackiego i jego wpływu na odbiorcę właściwy Konwickiemu opisać można zarówno przy użyciu hermeneutycznej kategorii horyzontu Hansa-Georga Gadamera, jak i kategorii Inności wywiedzionej przez Dereka Attridge’a $z$ filozofii spotkania Emmanuela Levinasa. Tekst według Konwickiego odgrywa rolę Innego. Zgodnie $z$ odczytaniem filozofii Levinasa przez Attridge'a literatura, ukazując protagonistom ograniczenia obowiązujące w rzeczywistości, afirmuje Inność jako sferę modyfikacji istniejących modeli. Doświadczenie takiej możliwości zarówno prowokuje do tworzenia, jak i zachęca do wędrowania, które u Konwickiego bywa tożsame $z$ aktem kreacji i opowiadaniem. Inność, ujawniająca się w procesie obcowania $z$ literatura, wymusza zmianę w podmiocie. Jej uświadomienie owocuje procesem samopoznania, otwiera relację między obecnością a brakiem, między tym, co istnieje, a tym, co jest potencjalne, między ego a alter ego, podmiotem a jego sobo-

70 Ibidem, s. 356-358. Problem ten interesował również innych badaczy. B. Ży n is („To jest Konwicki, czy nie jest?” O podmiotowości sylleptycznej. „Litteraria Copernicana” 2008, nr 1, s. 58), opisując sposób kreowania podmiotowości przez Konwickiego, jego gry z prawdą i mitologizowaniem, odwołała się do figury syllepsis: „Nie chodzi wyłącznie o to, że nie można oddzielić empirii od pisma (fikcji), ale o to, że tekst i "życie" stanowią swego rodzaju wstęgę Moebiusa - przejście między nimi jest płynne, linia graniczna nie do wskazania. Nieprzeczytane książki "nie żyją", niepodlegające narracji życie - nie istnieje”.

71 Zob. Ch. Taylor, Etyka autentyczności. Przeł. A. Pawele c. Kraków 2002, s. 87: „najwięksi pisarze XX wieku nie są subiektywistami w tym znaczeniu. Ich tematu nie stanowi podmiot, lecz coś poza nim. Rilke, Eliot, Pound, Joyce, Mann - to niektórzy z nich. Autorzy ci sa przykładem tego, że nieuchronne zakotwiczenie języka poetyckiego w indywidualnej wrażliwości nie jest tożsame z zamknięciem poety w granicach własnej jaźni. Rilke, na przykład, próbuje w swoich Elegiach duinejskich powiedzieć nam coś o naszym losie, o związkach łączących żywych z umarłymi, o ludzkiej kruchości i o mocy przeistoczenia zawartej w języku”. 
wtórowymi odbiciami i fakultatywnymi konstrukcjami (przykładem mogą być tu odmienne wersje życiorysu bohatera Wniebowstapienia), między wzniosłością a przyziemnością, prawdą a zmyśleniem, autentyzmem a plagiatem ${ }^{73}$.

Podmiot ma w twórczości Konwickiego charakter relacyjny, tworzy się, podlega „sprawdzeniu” $\mathrm{i}$ wartościowaniu w kontakcie $\mathrm{z}$ Innym, co wyraża się chociażby przez niezwykle popularny u autora Bohini motyw spotkania $z$ własnym sobowtórem ${ }^{74}$. Podobnie jest ze snutymi przez pisarza narracjami. Dokonując ironicznej parabazy, często kompromituje on światy powoływane przez siebie do istnienia. Jan Walc za podstawową zasadę kompozycyjną utworów Konwickiego uznał występowanie różniących się między sobą narracji, z których jedna wydaje się nadrzędna, pozoruje realizm ${ }^{75}$.

Spotkanie $\mathrm{z}$ innością, $\mathrm{z}$ literatura jest formą kreacji samego siebie. Jest sposobem budowania podmiotowości opartej na relacyjności, procesualności i niedookreśloności. Postacie Konwickiego egzystuja „pomiędzy” - balansują pomiedzy ekstremami alienacji i przynależności, ich byt należałoby określić jako paradoksalny.

„Inny” w tej sytuacji nie jest więc, ściśle rzecz biorąc, o s o b a [...], jest on relacją - albo relacyjnością - między mna jako tym samym i tym, co w swojej niepowtarzalności jest heterogeniczne wobec mnie i rozbija moją tożsamość 〈sameness〉. Jeśli uda mi się adekwatnie odpowiedzieć na inność i jednostkowość innego, odpowiadam na innego w jego relacji do mnie - zawsze w określonym czasie i przestrzeni - twórczo zmieniając siebie i być może również odrobinę świat ${ }^{76}$.

Reguła ta nie ogranicza się tylko do relacji: bohater - alter ego, ale odnosi się także do związków między autorem a jego sobowtórem (postacią) czy wręcz do relacji łączącej autora i czytelnika.

Dla Konwickiego opowiadanie to jedyny sensowny, choć paradoksalny, sposób istnienia. Tragiczna w swojej niedoskonałości i uwikłaniu w świat, a zarazem heroiczna w iście Conradowskim czy Herbertowskim - jak pisze Walc - nakazie ciągłego ponawiania trudu, wierności do końca ${ }^{77}$, wizja antropologii, jaka proponuje Konwicki, mieści się w formule homo narrans. Literatura, opowiadanie, w którym to akcie komunikacyjnym zawarty jest model spotkania, daje możliwość zbliżenia horyzontów, prawdziwego, głębokiego kontaktu z drugim człowiekiem, nieistotne żywym czy umarłym, przodkiem czy współczesnym, literackim poprzednikiem czy wiernym czytelnikiem ${ }^{78}$. Przekonanie Konwickiego o takim quasi-sakralnym zna-

Kordy s (op. cit., s. 238-243) pokazuje np., jak odpowiednie użycie fikcji narracyjnej stosowane bywa w czasie terapii psychoanalitycznej i paradoksalnie wiedzie do prawdy o ukrytych traumach pacjenta.

74 Jest to niezwykle ważny motyw w twórczości Konwickiego. Już W alc (op. cit., s. 38) uznał, że adwersarze ideowi protagonistów Konwickiego odzwierciedlają wątpliwości gnębiące samego narratora. Ponadto postawił jako pierwszy tezę, że nie są oni ontologicznie niezależni, ale stanowią alter ego bohatera. Badacz analizował przede wszystkim Sennik wspótczesny-zob. ibidem, s. 104, 108, 139-151. Szerzej na temat aspektów mitycznych i psychologicznych problemu zob. M. Kłobuk ow ski, Narcyz mityczny, romantyczny i współczesny. Przemiany archetypu sobowtóra $w$ literaturze XIX i XX wieku. W zb.: Don Kichot i inni. Postacie mityczne $w$ perspektywie komparatystycznej. Red. L. Wiśni ew ska. Bydgoszcz 2012, s. 57-81.

W alc, op. cit., s. 8.

D. At tridg e, Jednostkowość literatury. Przeł. P. M o ś c i c ki. Kraków 2007, s. 56.

W al c, op. cit., s. 36-37, 86-87.

W a lc (ibidem, s. 45) nazwał książki Konwickiego poszukiwaniem wartości i procesem, „w którym 
czeniu literatury ma proweniencje romantyczną. Tworzenie i czytanie literatury jawi się jako wielki obrzęd, w którym człowiek wykluczony, „oszukany przez historię"79 ma szansę budować więzi z Innym. Ten ostatni natomiast okazuje się zaskakująco bliski, pomaga wykreować czy też zweryfikować własną tożsamość ${ }^{80}$. Jak słusznie zauważyła Joanna Cieplińska, Konwicki konstruuje podmiot w oparciu o konfabulacyjną grę:

najbezpieczniejsza jest gra w prawdę i fałsz, która niekoniecznie prowadzi do poczucia wolności, choćby złudnej, ale która jest dla pisarza rodzajem psychicznego alibi. Kreowanie podwójnej tożsamości to nie tylko wytwarzanie mitu o sobie samym, ale również działanie unikowe, kompensacyjne, które daje szansę na ucieczkę od przeszłości lub teraźniejszości ${ }^{81}$.

\section{Konwickiego źródła autentyczności}

Książka, dobra czy zła, jest portretem własnym autora ${ }^{82}$.

Konwickiemu tworzenie literatury wydaje się pozbawione sensu, jeśli pomimo fikcyjności i konwencjonalności przedstawień, wbrew autonomii rozmaitych artystycznych zabiegów i gier nie prowadzi do autentycznego przeżycia, zarówno czytelnika, jak i autora.

Otóż jest jakaś żyła, jakiś niewidoczny nerw, jakiś strumień jonów, który nadaje energię, wyrazistość, nasyca bioprądami tak zwane dzieło sztuki.

[...] Przez owo dzieło sztuki przepływa zmienny prąd, którego generatorem jest autor.

Podobnie bywa $z$ literaturą. Oddech autora, linie papilarne palców, ślady jego chorób, nastrojów, rozpaczy, to wszystko jest zawarte w dwudziestu ośmiu albo trzydziestu dwóch znakach alfabetu. W składni zdań i doborze słów, w rytmie usposobień i prawie nieuchwytnym tętnie przeczuć tej tajemnicy, która nas gnębi od czasów, gdy zleźliśmy z drzew ${ }^{83}$.

Bohaterowie kreowani przez autora Małej apokalipsy dziedziczą swoisty kult literatury po swych literackich antenatach $z$ epoki romantyzmu. „Zbójeckie księgi" ${ }^{84}$ odgrywają dwoistą rolę nie tylko w życiorysach XIX-wiecznych protagonistów,

to, co pochodzi od pisarza, łączy się niepostrzeżenie z tym, co pochodzi od czytelnika". Zob. też Z. Ta r a ni en ko, Wspótautorstwo czytelnika. Rozmowa z Tadeuszem Konwickim. W: Rozmowy z pisarzami. Warszawa 1986, s. 257-258: „Mnie już trochę znudziło pisać samotnie. Postanowiłem od pewnego czasu pisać z czytelnikiem. I to mi sprawia przyjemność. Cała moja gra idzie w tym kierunku [...], że usiłuję cały czas wciaggnąc czytelnika do współpracy".

79 A. N a sals ka, Oszukani przez historię. O prozie Tadeusza Konwickiego. W zb.: Między literatura a historia. Red. E. Ło ch. Lublin 1986.

80 Zob. P. Ric o e u r, O sobie samym jako innym. Przeł. B. Ch eł s to w s ki. Naukowe oprac., wstęp M. Kowals ka. Warszawa 2003.

81 J. Cieplińska, Gry i idee, czyli biograficzne wariacje Tadeusza Konwickiego. „Litteraria Copernicana” 2008, nr 1, s. 43. Zob. też J a ni o n, op. cit., s. 149: „Na tym właśnie polega sztuka Konwickiego - na tworzeniu jednocześnie czegoś zarazem autentycznego i spreparowanego; [...] Konwicki dziedziczy po romantykach to szczególne rozumienie literatury, które utożsamia jej "Sztuczność" (od sztuki) z autentyzmem, poręczanym przez uczucie" (podobnie na s. 150-154). N ow i cki [B e r eś], op. cit., s. 150: „Jeśli już nawiązuję łączność z bliźnim, to w niczym go nie oszukuję. On dostrzega mnie w ferworze gier i zabiegów, które dla niego przygotowałem”. Konwicki, Pamflet na siebie, s. 105.

Ibidem, s. 88-89.

84 A. Mickiewicz, Dziady. Część IV, w. 155. W: Dzieła. Wyd. Rocznicowe. T. 3: Dramaty. Oprac. Z. Stefan owska. Warszawa 1995. 
ale także w losach postaci Konwickiego. Paweł z Sennika współczesnego został wychowany w tradycji romantycznego kultu książki. Czytał Popioły, co wpłynęło na podjęcie decyzji o udziale w partyzantce akowskiej. Nawet Tadzio Skórko, prowincjonalny chłopak z Małej apokalipsy, agent nasłany przez UB na głównego bohatera, zna na pamięć wszystkie powieści swego „podopiecznego”. Nosi za bohaterem kanister, darzy dwuznacznym uczuciem, w którym fascynacja łączy się z gotowością do zdrady. Niektórzy badacze ryzykują stwierdzenie, że jest jednym z sobowtórów autora ${ }^{85}$. Także protagonista Rzeki podziemnej, ptaków podziemnych - Siódmy - uważa się za poetę. Jego grafomańskie ${ }^{86}$ wiersze stereotypowo naśladują konwencje literackie, co także może świadczyć o specyficznym „uwięzieniu" w literaturze. Nieprzypadkowo dość często pojawia się w powieściach Konwickiego motyw plagiatu czy przepisania historii, która gdzieś już i przez kogoś została opowiedziana. Dobrym przykładem jest Czytadło, gdzie natrafiamy zarówno na reminiscencje literackie z klasyki (autoironiczne wprowadzenie postaci Tony'ego Mickiewicza, dalekiego krewniaka wieszcza, którego Konwicki uwielbia cytować i trawestować ${ }^{87}$ ), jak i na aluzje do świata polityki czy popkultury. Czytadło to powieść, w której prawie każdy kogoś przypomina (podwaja, naśladuje, kopiuje) dla przykładu: sławnego aktora, byłego prezydenta Stanów Zjednoczonych czy Elvisa Presleya. Wiąże się to $\mathrm{z}$ poczuciem lęku podmiotu przed byciem „splagiatowanym". W jednym $z$ fragmentów świadomość tych powtórzeń, a równocześnie obawa przed nimi wyrażona została expressis verbis:

Może wyjdę na balkon i strasznym kosmicznym wrzaskiem nawymyślam całemu światu. Ale właśnie w tej chwili strażacy zdejmują $z$ dachu domu towarowego „Centrum” krzyczącego wariata. Uprzedził mnie. Koszmar plagiatów ${ }^{88}$.

Podobne uwagi zawarł Konwicki w Pamflecie na siebie. Stają się one okazją do poruszenia kwestii twórczego naśladownictwa, oryginalności i powtarzalności 89. Pisarz w pełni zdaje sobie sprawę, iż absolutna autentyczność nie jest możliwa. Naśladownictwo to dla niego „sobowtór oryginalności” 90 . Każdy akt twórczy jawi mu się jako mniej lub bardziej zależny od wzorców obcych lub własnych (nieprzypadkowo Konwicki bywa nazywany autorem jednej, ciągle pisanej książki) i równocześnie jest szansą na gest wielki i piękny, na dialog z czytelnikiem, $\mathrm{z}$ umarłymi ${ }^{91}$.

Zob. J. Arlt, Mój Konwicki. Kraków 2002, s. 13-30.

C zapliński, op. cit., s. 157.

Zob. A. F a bi a n ow s ki: Tadeusza Konwickiego myślenie Mickiewiczem. W zb.: Adam Mickiewicz i kultura światowa. Materiały Międzynarodowej Konferencji Naukowej, 12-17 maja 1997 roku. Grodno-Nowogródek, $w 5$ księgach. Ks. 4. Red. S. M u si en k a, M. Č a r m i n's ka. Grodno 1998; Konwicki, Odojewski i romantycy. Projekt interpretacji intertekstualnych, Kraków 1999; MickiewiczKonwicki. Przygoda intertekstualna. W zb.: Mickiewicz a literatury słowiańskie. Z dziejów recepcji od modernizmu do współczesności. Red. E. Ło c h. Lublin 2004. - M. Kło b u k ow s ki, Mityczna obecność Adama Mickiewicza w twórczości Tadeusza Konwickiego. „Wiek XIX. Rocznik Towarzystwa Literackiego im. Adama Mickiewicza” 2016.

T. Konwicki, Czytadło. Warszawa 1996, s. 175. Zob. też Ko nwicki, Nowy Świat $i$ okolice, s. 20-23.

Ko nw i cki, Pamflet na siebie, s. 108-116.

Ibidem, s. 111.

Ko n w i c ki: Wschody i zachody księżyca, s. 83-84; Nowy Świat i okolice, s. 6-7, 20-23; Kalendarz i klepsydra, s. 113, 224, 262, 333, 336. 
Powtarzanie rodzi szanse na dialog i stwarza dogodny ekran samorozumienia. Wszyscy ludzie, dokonując autoekspresji, jawią się w ten sposób jako artyści ${ }^{92}$. Jak udowadnia Charles Taylor, nowoczesna etyka autentyczności, realizowanie moralnego nakazu bycia samym sobą, bycia wiernym samemu sobie, nie może się urzeczywistnić bez samookreślenia, bez odnalezienia prawdy o sobie samym. W tym tkwi - w uproszczeniu - sens nowoczesnej autentyczności. Postromantyczne odkrywanie siebie przypomina twórczość artystyczną:

Twórczość artystyczna jest teraz czynnością wzorcową, instruującą ludzi, jak mogą dojść do samookreślenia. W pewnym sensie artysta okazuje się paradygmatem człowieka jako twórcy oryginalnego samookreślenia. [...]

$[\ldots]$

[...] odkrywam siebie poprzez moje dzieło, poprzez to, co tworze jako artysta ${ }^{93}$.

Reżyser Lawy już w latach pięćdziesiątych XX wieku wyraźnie zwątpił w sens posługiwania się fikcją, twierdząc, iż literatura nie jest w stanie uwolnić się od naśladowania życia. Każda „fikcja” podszyta jest autentyzmem pisarskich doświadczeń, emocji, zaangażowania, przefiltrowanych w wyobraźni artysty ${ }^{94}$. Być może, właśnie to przekonanie o konieczności posługiwania się przedziwnym splotem fikcji i prawdy, plagiatu i tekstu własnego sprawiło, że Konwicki stworzył formy nazwane przez krytyków sylwicznymi. Doskonałym przykładem są tu - „ł̇e-dzienniki”, w których dokonywał on permanentnych mitologizacji i mistyfikacji, łącząc je - jak można mniemać - ze szczerymi wyznaniami ${ }^{95}$. „Literatura faktu. Ja jestem faktem mojej literatury. Faktura Litwy. Literatura faktu. No i bardzo dobrze" - pisał o ważnym dla konstruowania własnej tożsamości wątku litewskim ${ }^{96}$. W innym miejscu nazwał swoją twórczość „rozpaczliwym autodokumentaryzmem z liryczna eschatologia w tle" 97 .

W tej wierności materii osobistego doświadczenia pozostał autor Nic albo nic dziedzicem romantyków. Taylor przypomina, że nowoczesna etyka autentyczności, nakazująca realizować ideał moralny wierności samemu sobie, korzeniami sięga schyłku wieku XVIII (tekstów Rousseau, Herdera) i rozwinąć się mogła między innymi dzięki sztuce romantycznej, która sprawiła, że wszelka poezja uległa u p o dmi otowieniug8. Nowoczesny twórca musi, będąc naturalnym spadkobierca romantyków, odnosić się do tradycji, zarazem kreując swój niepowtarzalny, oryginalny i osobisty język, powinien „wyartykułować oryginalną wizję kosmosu”99. W wypadku Konwickiego praktyka ta opierała się na zmitologizowaniu własnej biografii:

Zob. T. Ko nwicki, Wszyscy jesteśmy artystami. W: Wiatr i pył, s. 447-448.

Taylor, op. cit., s. 63.

Zob. T. Ko nw i cki, Jak napisać pierwsze opowiadanie? W: Wiatr i pył, s. 95-97.

Zob. K o n w i c ki, Kalendarz i klepsydra, s. 85: „Potem gra z prawdą staje się nałogiem. [...] prawda, która stała się faktem, wsącza się w atrament, rozpełza po manuskrypcie, przeżera zmyślone zdarzenia i wyimaginowane uczucia".

Konwicki, Nowy Świat i okolice, s. 190.

Konwicki, Pamflet na siebie, s. 87.

Taylor, op. cit., s. 86.

Ibidem, s. 83. 
Ja [...] wielokrotnie bezwstydnie eksponuję sam siebie. [...] Literaci na ogół trochę wstydzą się materiału biograficznego, udaja, że piszą z głowy, to znaczy z niczego. Ja jestem przypadkiem odwrotnym, robię - przepraszam za patetyczny termin - prozę kreacyjną, czyli całkowicie skomponowana przeze mnie. W obawie, żeby to nie stało się chłodne, ciężkie w odbiorze, wprowadzam siebie, usiłuję nadać temu, co piszę, prawie dokumentalny charakter osobistego zwierzenia. Zamiast uciekać od autobiografizmu, kłamię i narzucam się czytelnikowi ${ }^{100}$.

Konwicki na pytanie Stanisława Beresia o ciagłe zbliżanie się do „ja” odpowiadał, że gra autobiograficzna absolutnie nie ma walorów ludycznych, nie jest sposobem oszukiwania czytelnika, ale, paradoksalnie, przejawem autentyczności ${ }^{101}$ oraz forma racjonalizacji swojego bytu. Zarazem uzasadniał tendencje autodemaskatorskie:

Przecież to nie jest tylko gra, lecz również sublimacja autodemaskacji! [...] Przecież ja ciagle dokonuję usensownienia własnej egzystencji: żyjąc, biorąc udział w życiu społecznym, należąc lub nie należąc do partii, rozmawiając z Panem. Poza tym określam się, zapisuję myśli, utrwalam na wszelki wypadek. Dokładnie nie wiem, po $\mathrm{co}^{102}$.

Literatura jako wzór do naśladowania, jako pułapka po części alienującej powtarzalności (gdy ta jest bezrefleksyjna) jawi się równocześnie jako jedyny sposób na zdanie sprawy $z$ własnego losu. Jeśli nowoczesny ideał wierności samemu sobie oznacza odkrycie i wyrażenie swej potencjalności oraz indywidualności, niepowtarzalności, to - jak udowadnia Taylor - da się go urzeczywistnić tylko wówczas, gdy połączy on jednostkę $z$ większą wspólnotą, nawet w wypadku wcześniejszego zniszczenia owej więzi ${ }^{103}$. Zadanie to spełniają, a w każdym razie umożliwiają, literatura i tradycja.

Abstract

MIŁOSZ KŁOBUKOWSKI Włocławek

\section{TADEUSZ KONWICKI'S LITERARY GAMES WITH THE SUBJECT}

The aim of the article is an attempt at a synthetic view on the role ascribed to literature as seen in Tadeusz Konwicki's works. The author of the article analyses the problem both implicitly (in his consideration on the given creation of a literary protagonist and the world presented) and discursively (in statements given in silvae and in interviews with the writer). The image of literature and its influence on a man proves to be full of paradoxes. Composing and reading lead simultaneously to dangerous disappointments and feeling of alienation in the world, but also allows to construct a community. The author of the article refers e.g. to literary theory as to Derek Attridge's the other and to Hans-Georg Gadamer's hermeneutic category of horizon. He also searches for the sources of the writer's literary authenticity and comments them in reference to the modern ideals of ethics of authenticity proposed by Charles Taylor.

Ko nwi cki, Pamiętam, że było goraco, s. 147.

Można odnieść to do teorii nowożytnego zwrotu, o jakim pisze Taylor (op. cit., s. 31-35), na dobre zaistniałego właśnie w literaturze romantycznej, która wywarła ogromny wpływ na Konwickiego. Jeśli więc należy mówić o nowożytnej konstrukcji podmiotowości odnoszącej się do samej siebie (autentyzm) w celu wypełnienia ideału moralnego samorealizacji, to trzeba podkreślić, że Konwicki jest uczniem i kontynuatorem romantyków.

Nowi c ki [B e r eś], op. cit., s. 79.

Taylor, op. cit., s. 89. 